J. Clin. Chem. Clin. Biochem.

Vol. 19, 1981, pp. 145-154

\title{
Comparison of Substrates for Measuring Cystyl-Amino Peptidase Activity in Serum of Pregnancy and Hepatic Disease and in Various Tissues
}

\author{
By T. Uete, H. Motokura, Y. Kitano, C. Fukutani, N. Uenishi and N. Ando
}

Kitano Hospital, Tazuke Kofukai Medical Research Institute, kita-ku, Osaka City, Japan

(Received January 15/Augúst 5, 1980)

Summary: The specificity of substrates for measuring cystyl-amino peptidase activity in pregnant serum in the assessment of placental function was studied, using $L$-cystine-di- $\beta$-naphthylamide, $L$-cystine-bis- $p$-nitroanilide, $L$-cysteine- $\beta$ naphthylamide, and S-benzyl- $L$-cysteine- $p$-nitroanilide. The enzyme activity with $S$-benzyl- $L$-cysteine- $p$-nitroanilide increased more rapidly and markedly than with other substrates with advancing gestation. At term, the highest value was obtained with $S$-benzyl- $L$-cysteine- $p$-nitroanilide, followed by $L$-cysteine- $\beta$-naphthylamide and cystineamides. The cystyl-amino peptidase activity with these substrates in pregnant serum was well correlated with the plasma oestriol level.

In the serum of normal individuals and in patients with hepatic disease, the highest catalytic activity was obtained with $L$-cysteine- $\beta$-naphthylamide, followed by S-benzyl- $L$-cysteine-p-nitroanilide and cystineamides. In hepatic disease, the enzyme activity with $L$-cysteine- $\beta$-naphthylamide was markedly increased, but that with other substrates was only slightly enhanced.

In the placenta, brain, heart and liver, the highest catalytic activity was observed with S-benzyl- $L$-cysteine-p-nitroanilide and the enzyme activity pattern was similar to that in pregnant serum. However, in the kidney and small intestine the enzyme activity was highest with $L$-cysteine- $\beta$-naphthylamide, followed with $S$-benzyl- $L$-cysteine-p-nitroanilide and cystineamides.

The enzyme activity with $S$-benzyl- $L$-cysteine-p-nitroanilide in various sera was inhibited by $\mathrm{Co}^{2+}$, but that with $L$-cysteine $\beta-\beta$-naphthylamide was stimulated by this ion. The purified oxytocinase has been reported to be inhibited by $\mathrm{Co}^{2+}$. Therefore, the present observations suggest high efficacy of S-benzyl- $L$-cysteine-p-nitroanilide for measuring oxytocinase activity for the assessment of placental function.

Vergleich von Substraten für die Bestimmung von Cystyl-Aminopeptidase im Serum bei Schwangerschaft, Lebererkrankungen und in verschiedenen Geweben

Zusammeñunfassung: Die Spezifität der Substrate $L$-Cystin-di- $\beta$-naphthylamid, $L$-Cystin-bis-p-nitranilid, $L$-Cystein$\beta$-naphthylamid und S-Benzyl- $L$-cystein-p-nitranilid zur Bestimmung von Cystyl-aminopeptidase im Serum Schwangerer für die Beurteilung der Placentafunktion wurde untersucht. Mit S-Benzyl- $L$-cystein-p-nitranilid wurde mit fortschreitender Schwangerschaft ein schnellerer und deutlicherer Anstieg als bei Verwendung anderer Substrate beobachtet. Beim Gëburtstermin wurden die höchsten Werte mit S-Benzyl-L-cystein-p-nitranilid erhalten, gefolgt von $L$-Cystein- $\beta$-naphthylamid und den Cystinamiden. Die mit diesen Substraten erhaltenen Cystyl-Aminopeptidasewerte im Șerum Schwangerer korrelierten gut mit der Östriolkonzentration im Plasma. Im Serum Gesunder und von Patienten mit Lebererkrankungen wurde die höchste katalytische Aktivität mit $L$-Cystein- $\beta$-naphthylamid erreicht, gefolgt von S-Benzyl-L-cystein-p-nitranilid und den Cystinamiden. Mit $L$-Cystein- $\beta$-naphthylamid zeigten sich bei Lebererkrankungen deutlich erhöhte, mit den anderen Substraten nur gerịng erhöhte katalytische Aktivitäten.

In Placenta, Gehirn, Herz und Leber wurde ähnlich den Ergebnissen im Schwangerenserum die höchste katalytische Aktivität bei Verwendung von S-Benzyl-L-cystein-p-nitroanilid gemessen. In Niere und Dünndarm jedoch war die katalytische Aktivität mit $L$-Cystein- $\beta$-naphthylamid am höchsten, gefolgt von S-Benzyl- $L$-cystein-p-nitranalid und den Cystinamiden. 
Die katalytische Aktivität in zahlreichen Seren wurde bei Messungen mit S-Benzyl- $L$-cystein-p-nitranilid durch $\mathrm{Co}^{++}$ gehemmt, jedoch bei Messungen mit $L$-Cystein- $\beta$-naphthylamid von diesem Ion stimuliert. Gereinigte Oxytocinase soll von $\mathrm{Co}^{++}$gehemmt werden. Deshalb weisen die vorgelegten Beobachtungen auf einen Vorzug von S-Benzyl- $L$-cystein$p$-nitranilid zur Messung der Oxytocinase für die Beurteilung der Placentafunktion hin.

\section{Introduction}

Serum cystyl-amino peptidase (EC 3.4.11.3) catalytic activity is known to increase with advancing gestation, the highest levels being found at term $(1-16)$. Serial serum cystyl-amino peptidase estimations appear to be helpful in the diagnosis of placental failure (17-20) and the management of intrauterine fetal growth retardation and fetal distress, etc (21-27), but there is some controversy $(28-32)$. This may be the consequence of differences in various methods used for the enzymes assay.

For the assay of cystyl-amino peptidase activity in serum or plasma, cystineamides such as $L$-cystine-di- $\beta$-naphthylamide (33-38) and $L$-cystine-bis- $p$-nitroanilide (39-49) have been used as substrate. Cysteineamides, e.g. $S$-benzyl- $L$-cysteine- $\beta$-naphthylamide (50), $L$-cysteine$\beta$-naphthylamide (51) and S-benzyl- $L$-cysteine- $p$-nitroanilide $(52-58)$ have also been used. Greater sensitivity occurs with the cysteineamides compared with the cystineamides. However, it remains to be clarified as to which substrate is most useful for assessing placental function.

In this investigation, in order to obtain information concerning the efficacy of substrates for measuring cystylamino peptidase activity in the assessment of placental function, the enzyme activity in various sera and tissues was studied using $L$-cystine-di- $\beta$-naphthylamide, $L$-cystinebis- $p$-nitroanilide, $L$-cysteine- $\beta$-naphthylamide and $S$ benzyl- $L$-cysteine-p-nitroanilide. The enzyme activity in pregnant serum was also evaluated by comparison with the serum oestriol level, which is a reliable index of the feto-placental unit $(59,60)$.

\section{Materials and Methods}

\section{Reagents}

L-Cystine-di- $\beta$-naphthylamide solution

$1 \mathrm{mmol} / 1$ in $0.05 \mathrm{~mol} / 1$ cacodylate buffer at $\mathrm{pH}$ 6. $L$-Cystinedi- $\beta$-naphthylamide (Sigma Chem. Co.) is dissolved in a small amount of water by adding dropwise $1 \mathrm{~mol} / 1 \mathrm{HCl}$. Excess $\mathrm{HCl}$ should not be used. Thereafter, the $\mathrm{pH}$ is brought to 6 with $\mathrm{NaOH}$. Cacodylate buffer, $\mathrm{pH} 6$, and water are then added.

\section{L-Cyst eine- $\beta$-naphthylamide solution}

$1.5 \mathrm{ml}$ of $L$-cystine-di- $\beta$-naphthylamide, $1 \mathrm{mmol} / 1$ in 0.05 mol/1 cacodylate buffer, $\mathrm{pH} 6$, is treated with $0.1 \mathrm{ml}$ of 25 $\mathrm{mmol} / 1$ mercaptoethanol at $37^{\circ} \mathrm{C}$ for $15 \mathrm{~min}$. In the presence of a thiol, such as mercaptoethanol or reduced glutathione, $L$-cystine-di- $\beta$-naphthylamide is converted to $L$-cysteine- $\beta$ naphthylamide (51).

\section{L-Cystine-bis-p-nitroanilide solution}

$L$-Cystine-bis-p-nitroanilide (Nakarai Chem. Co.), $3.5 \mathrm{mmol} / 1$ in acetone/methanol mixture $(100 \mathrm{ml}+900 \mathrm{ml})(58)$.

\section{S-Benzyl-L-cysteine-p-nitroanilide solution}

S-Benzyl- $L$-cysteine-p-nitroanilide (Nakarai Chem. Co.) 6.9 $\mathrm{mmol} / \mathrm{l}$ in acetone/methanol (100 $\mathrm{ml}+900 \mathrm{ml})$ (58).

p-Dimethylaminocinnamaldehyde, reagent, freshly prepared before use.

p-Dimethylaminocinnamaldehyde (Nakarai Chem. Co.), $20 \mathrm{mg}$, is dissolved in $20 \mathrm{ml}$ of methanol and dimethyl sulfoxide $(1+1)$ mixed with $10 \mathrm{ml}$ of mercaptoethanol $(25 \mathrm{mmol} / \mathrm{l})$ and $1.5 \mathrm{ml}$ $1.0 \mathrm{ml}$ of $2 \mathrm{~mol} / 1 \mathrm{HCl}$ are added.

\section{Methanol/dimethylsulfoxide reagent}

Methanol and dimethyl sulfoxide $(1+1)$ mixture, $20 \mathrm{ml}$ is mixed with $10 \mathrm{ml}$ of mercaptoethanol $(25 \mathrm{mmol} / \mathrm{l})$ and $1.5 \mathrm{ml}$ of $2 \mathrm{~mol} / 1 \mathrm{HCl}$

\section{$E_{3}$-Riapac kit}

Radiochemical Center, England.

\section{Procedure}

\section{Cystyl-amino peptidase assay in serum}

a) With $L$-cystine-di- $\beta$-naphthylamide or $L$-cysteine- $\beta$-naphthylamide: $L$-Cystine-di- $\beta$-naphthylamide $(1 \mathrm{mmol} / 1 \mathrm{in} 0.05 \mathrm{~mol} / 1$ cacodylate buffer, $\mathrm{pH} \mathrm{6}$ ) solution $1.5 \mathrm{ml}$, is preincubated with and without $0.1 \mathrm{ml}$ of thiol solution $(25 \mathrm{mmol} / 1$ mercaptoethanol) at $37^{\circ} \mathrm{C}$ for $15 \mathrm{~min}$. A serum sample $0.05 \mathrm{ml}$ is mixed with the above solution and inbubated at $37^{\circ} \mathrm{C}$ for $15 \mathrm{~min}$. $p$-Dimethylaminocinnamaldehyde color reagent $2.0 \mathrm{ml}$ is then added. After $15 \mathrm{~min}$, the absorbance is determined at $540 \mathrm{~nm}$. For a control, the reaction mixture without serum is similarly incubated. After incubation, $p$-dimethylaminocinnamaldehyde color reagent and serum sample are added. $\beta$-Naphthylamine standards, 0.5 and $1 \mu \mathrm{g}$, are prepared in the reaction mixture in the same way as the test sample, but without serum.

b) With $L$-cystine-bis- $p$-nitroanilide or S-benzyl- $L$-cysteine- $p$ nitroanilide: $L$-Cystine-bis- $p$-nitroanilide $(3.5 \mathrm{mmol} / 1)$ or $\mathrm{S}$ benzyl- $L$-cysteine- $p$-nitroanilide $(6.9 \mathrm{mmol} / 1), 0.1 \mathrm{ml}$, is mixed with $1.0 \mathrm{ml}$ of tris (hydroxymethyl)aminomethane buffer $(0.1$ $\mathrm{mol} / \mathrm{l}, \mathrm{pH} 7.2$ ) and incubated with $0.05 \mathrm{ml}$ of serum at $37^{\circ} \mathrm{C}$ for 15-30 min, followed by addition of p-dimethylaminocinnamaldehyde color reagent $2.0 \mathrm{ml}$. After $15 \mathrm{~min}$, the absorbance is determined at $565 \mathrm{~nm}$. For a control, the reaction mixture without serum is similarly incubated. After incubation, $p$-dimethylaminocinnamaldehyde color reagent and serum specimen are added. $p$-Nitroaniline standards, 5 and $10 \mu \mathrm{g}$, are prepared in the same reaction mixture as the test sample, but without serum.

Alternately, after incubation of the reaction mixture $2.0 \mathrm{ml}$ of methanol-dimethyl sulfoxide mixture containing mercaptoethanol and $\mathrm{HCl}$ without $p$-dimethylaminocinnamaldehyde is added and the absorbance is determined at $405 \mathrm{~nm}$. For a control, the reaction mixture without serum is similarly incubated, followed by addition of the above reagent and serum.

\section{Cystyl-amino peptidase assay in tissues}

Various wet tissues, $20-50 \mathrm{~g}$, were homogenized in 1 liter of tris (hydroxymethyl) aminomethane buffer (0.1 mol/1, pH 7.2). The enzyme activity is measured as in the case of serum enzyme 
using $0.05 \mathrm{ml}$ of tissue homogenate. After incubation, $0.4 \mathrm{ml}$ of $250 \mathrm{~g} / 1$ trichloroacetic acid is added and the mixture is centrifuged at $3.000 \mathrm{rpm}$ for $10 \mathrm{~min}$. Supernatant, $1 \mathrm{ml}$, is mixed with $2 \mathrm{ml}$ of $p$-dimethylaminocinnamaldehyde color reagent and $15 \mathrm{~min}$ later absorbance is measured.

\section{Calculation}

Enzyme activity is expressed as moles of $\beta$-naphthylamine or $p$ nitroaniline liberated from the substrate per liter of serum or per $\mathrm{mg}$ of tissue protein per minute at $37^{\circ} \mathrm{C}$.

\section{Serum oestriol (total) assay}

$E_{3}$-Riapac kit (Radiochemical Center, England) was used according to the manufacturer's instructions.

\section{Protein determination}

Protein in various tissue homogenates and serum was measured by the biuret method (61).

\section{A naly tical variables}

Effect of $p H$ on liberation of $\beta$-naphthylamine or p-nitroaniline from the substrates

The maximal rate of hydrolysis of the naphthylamine amides of cystine and cysteine by serum or various tissue was observed at about pH 6 under the conditions of the present method with cacodylate, tris(hydroxymethyl)aminomethane-maleate, or citrate-phosphate buffer (fig. 1). The maximal rate of hydrolysis of the nitroaniline amides of cystine and cysteine by the peptidases in serum or various tissues was found at about $\mathrm{pH} 7$ (fig. 1).

\section{Substrate concentration} solvent for $L$-cystine-bis-p-nitroanilide and S-benzyl- $L$-cysteine-
Ethylene glycol monomethyl ether was used previously as a

$p$-nitroanilide $(52,53)$. However, higher activities have been reported with acetone/methanol $(100 \mathrm{ml}+900 \mathrm{ml})(58)$. In this study, we confirmed this finding (tab. 1). With the concentration of $L$-cystine-di- $\beta$-naphthylamide, $L$-cysteine$\beta$-naphthylamide, $L$-cystine-bis-p-nitroanilide and S-benzyl- $L$ cysteine-p-nitroanilide used in this study, maximal enzyme activity was observed under the conditions of the present method.

Correlation between units of catalytic activity and amounts of serum or tissue homogenate, or incubation time

Under the conditions of this method, with $0.025,0.05$, and 0.075 $\mathrm{ml}$ of serum or tissue homogenates, $\beta$-naphthylamine or $p$-nitroaniline liberated from substrates was linearly correlated with incubation time for as long as $45 \mathrm{~min}$ and also with the amounts of serum or tissue homogenates, showing greater values with cysteineamides than with the corresponding cystineamides.

Tab. 1. Comparison of solvents for the substrate in the measurement of cystyl-amino peptidase activity.

\begin{tabular}{|c|c|c|}
\hline \multirow[b]{2}{*}{$\begin{array}{l}\text { Case } \\
\text { No. }\end{array}$} & \multicolumn{2}{|c|}{$\begin{array}{l}p \text {-Nitroaniline liberated at } 37^{\circ} \mathrm{C} \text { from } \\
\text { S-benzyl- } L \text {-cysteine- } p \text {-nitroanilide } \\
{[\mu \mathrm{mol} / \mathrm{min} \cdot 1]}\end{array}$} \\
\hline & $\begin{array}{l}\text { Ethylene gly } \infty 1 \\
\text { monomethyl ether }\end{array}$ & $\begin{array}{l}\text { Acetone/methanol } \\
\text { mixture }\end{array}$ \\
\hline $\begin{array}{l}\text { 1. Normal \& } \\
\text { 2. Normal \& } \\
\text { 3. Pregnancy } 24 \text { weeks } \\
\text { 4. Pregnancy } 30 \text { weeks } \\
\text { 5. Pregnancy } 30 \text { weeks } \\
\text { 6. Pregnancy } 30 \text { weeks }\end{array}$ & $\begin{array}{r}1.34 \\
1.84 \\
28.39 \\
55.11 \\
77.32 \\
101.87\end{array}$ & $\begin{array}{r}4.18 \\
3.34 \\
53.77 \\
106.88 \\
87.34 \\
121.58\end{array}$ \\
\hline
\end{tabular}

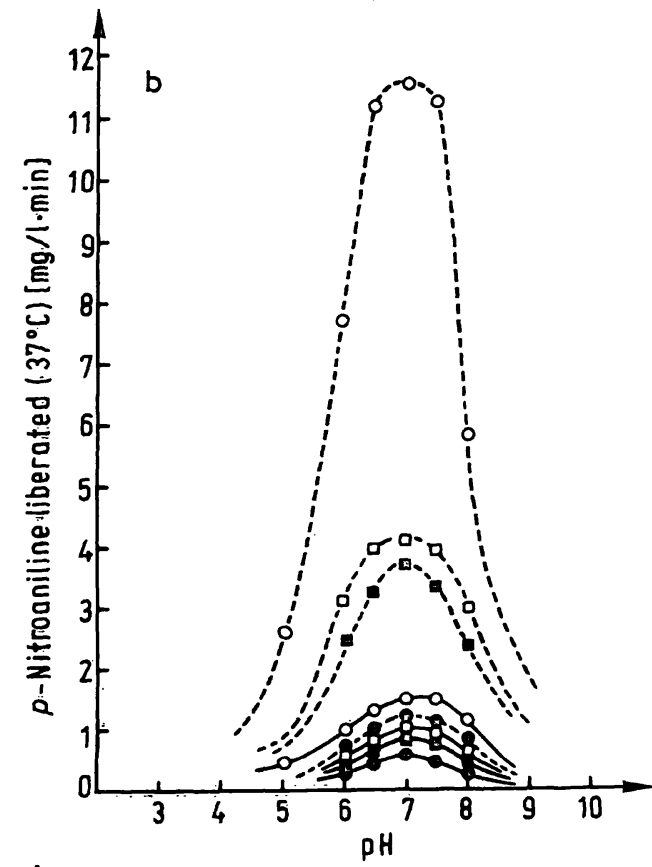

Fig. 1. Effect of $\mathrm{pH}$ on liberation of $\beta$-naphthylamine or $p$-nitroaniline from naphthylamides and nitroanilides.
a) Substrates: $L$-cystine-di- $\beta$-naphthylamide
$L$-cysteine- $\beta$-naphthylamide (-----)

b) Substrates: $L$-cystine-bis-p-nitroanilide $(-)$

S-benzyl- $L$-cysteine-p-nitroanilide (-.----)

- normal serum, opregnant serum, - hepatitis serum, a placental homogenate. 
Colour reactions of $\beta$-naph thylamine or p-nitroaniline with $p$ dimethylaminocinnamaldehyde

Originally, $p$-dimethylaminocinnamaldehyde was used for the determination of various amines (62). In addition, $p$-dimethylaminocinnamaldehyde was used for measuring $\beta$-naphthylamine in the assay of leucine aminopeptidase activity (63). For measuring $\beta$-naphthylamine, previous workers used a $p$-dimethylaminocinnamaldehyde reagent consisting of $0.3 \mathrm{~g}$ of $p$-dimethylaminocinnamaldehyde in $1000 \mathrm{ml}$ of ethanol containing $3.5 \mathrm{~g} \mathrm{HCl}(63)$. In their system, a serum or plasma specimen less than $0.02 \mathrm{ml}$, must be used, otherwise serum protein will be precipitated, resulting in turbidity of the reaction mixture.

In this study, the $p$-dimethylaminocinnamaldehyde reagent was improved by modifying the $\infty$ ncentration of $p$-dimethylaminocinnamaldehyde and $\mathrm{HCl}$ and by using a methanol-dimethyl sulfoxide $(1+1)$ mixture and mercaptoethanol With this improved reagent, $\beta$-naphthylamine and $p$-nitroaniline in the assay system were measured with greater sensitivity and without turbidity of the reaction mixture (tab. 2). The color developed is stable for at least $60 \mathrm{~min}$. The maximal absorption of color was obtained at $540 \mathrm{~nm}$ with $\beta$-naphthylamine and $565 \mathrm{~nm}$ with $p$-nitroaniline.

\section{Measurement of p-nitroaniline with methanol/dimethylsulfoxide reagent}

$p$-Nitroaniline liberated from the substrate was determined after the addition of methanol-dimethyl sulfoxide mixture containing $\mathrm{HCl}$ and mercaptoethanol without $p$-dimethylaminocinnamaldehyde to the reaction mixture. By this system, a simple and sensitive assay can be carried out without turbidity of the reaction mixture. When trichloroacetic acid is used to precipitate protein in the reaction mixture (58), the molar absorptivity of $p$-nitroaniline is markedly reduced (tab. 3). The present method is more sensitive and has the advantage of omitting centrifugation as compared with the previous spectrophotometric end-point method (58) (tab. 3).

The molar absorptivity of $p$-nitroaniline is not constant, but depends on the conditions under which it is measured. It is strongly concentration-dependent, and it is influenced by the ionic strength of solution (64). In this study, it was observed that when the $\mathrm{pH}$ of the solution was lowered the molar absorptivity was markedly reduced. The $\mathrm{pH}$ value of the reac tion mixture of the present method was significantly higher than that of Durham's method (58) (1.6 vs 1.1), and the molar absorptivity was therefore higher.

Tab. 2. Comparison of the $p$-dimethylaminocinnamaldehyde color reagent of previous workers (63) and that used in the present method.

\begin{tabular}{|c|c|c|}
\hline & Absorbance & \\
\hline & $\begin{array}{l}\text { Previous workers' } \\
\text { reagent }\end{array}$ & Present reagent \\
\hline \multicolumn{3}{|c|}{$\begin{array}{l}\beta \text {-Naphthylamine } \\
\text { at } 540 \mathrm{~nm}\end{array}$} \\
\hline $\begin{array}{l}1.9 \mu \mathrm{mol} / 1 \\
3.8 \mu \mathrm{mol} / 1\end{array}$ & $\begin{array}{l}0.065 \\
0.130\end{array}$ & $\begin{array}{l}0.130 \\
0.260\end{array}$ \\
\hline \multicolumn{3}{|l|}{$\begin{array}{l}p \text {-Nitroaniline } \\
\text { at } 565 \mathrm{~nm}\end{array}$} \\
\hline $\begin{array}{l}18 \mu \mathrm{mol} / 1 \\
36 \mu \mathrm{mol} / 1\end{array}$ & $\begin{array}{l}0.065 \\
0.130\end{array}$ & $\begin{array}{l}0.162 \\
0.325\end{array}$ \\
\hline
\end{tabular}

Reagent of Matsutani et al (63): $0.3 \mathrm{~g} p$-dimethylaminocinnamaldehyde in $1000 \mathrm{ml}$ of ethanol containing $3.5 \mathrm{~g} \mathrm{HCl}$. Present reagent: $1 \mathrm{~g} p$-dimethylaminocinnamaldehyde in $1000 \mathrm{ml}$ of methanol-dimethylsulfoxide $(1+1)$ mixture containing $3.3 \mathrm{~g} \mathrm{HCl}$ and $0.089 \mathrm{~g}$ mercaptoethanol.
Tab. 3. Comparison of absorbance of $p$-nitroaniline in the method of Durham (58) and the present method.

\begin{tabular}{|c|c|c|c|}
\hline & \multirow{2}{*}{$\begin{array}{l}\text { Durham's } \\
\text { method } \\
\text { A } 405 \mathrm{~nm}\end{array}$} & \multicolumn{2}{|c|}{ Present method with } \\
\hline$\cdot$ & & $\begin{array}{l}\text { methanol/ } \\
\text { dimethyl- } \\
\text { sulfoxide } \\
\text { reagent } \\
\text { A405 nm }\end{array}$ & $\begin{array}{l}p \text {-dimethyl- } \\
\text { aminocinn- } \\
\text { amaldehyde } \\
\text { reagent } \\
\text { As65 nm }\end{array}$ \\
\hline \multicolumn{4}{|l|}{$p$-Nitroaniline } \\
\hline $\begin{array}{l}18 \mu \mathrm{mol} / 1 \\
36 \mu \mathrm{mol} / 1\end{array}$ & $\begin{array}{l}0.098 \\
0.196\end{array}$ & $\begin{array}{l}0.220 \\
0.450\end{array}$ & $\begin{array}{l}0.160 \\
0.325\end{array}$ \\
\hline
\end{tabular}

\section{Reproducibility and precision}

The reproducibility of the enzyme assay (with $L$-cysteine- $\beta$ naphthylamide $n=30, \bar{x}=18.3, S D=0.57, C V=3.1 \%$; with S-benzyl- $L$-cysteine- $p$-nitroanilide $n=10, \bar{x}=145.3, S D=3.0$, $\mathrm{CV}=2.1 \%$ ) and recovery rate of $\beta$-naphthylamine or $p$-nitroaniline added to serum (98 to $102 \%$ ) were excellent. In the presence of bilirubin in serum at concentrations up to $10 \mathrm{mg} / \mathrm{dl}$, color development was not significantly influenced when the serum blank was used.

Correlation between results obtained by the present $p$-dimethylaminocinnamaldehyde colorimetric or methanol/dimethyl sulfoxide reagent method and the method based on the BrattonMarshall reaction

A good correlation between the results obtained by the present colorimetric or methanol/dimethyl sulfoxide reagent method and by the method with the Bratton-Marshall reaction (65) was observed, indicating the reliability of the present method (fig. 2 and 3).

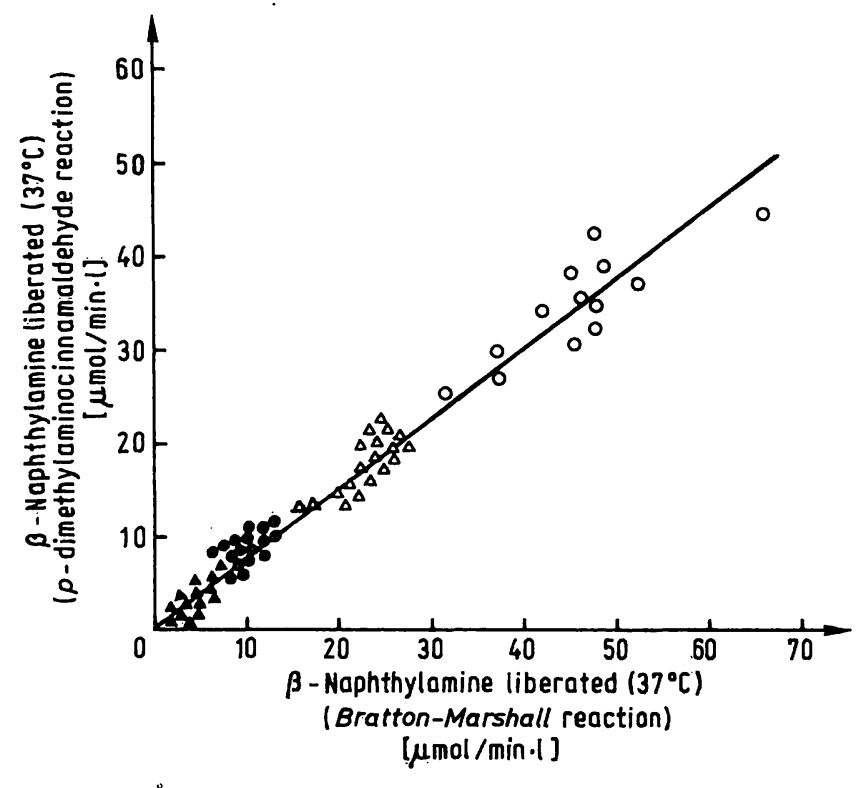

Fig. 2. Correlation between results of hydrolysis of naphthylamides obtained by the present colorimetric method and the method with the Bratton-Marshall reaction.

Normal serum with $\Delta$ cystineamide and $\Delta$ cysteineamide. Pregnant serum with $\bullet$ cystineamide and 0 cy śteineamide. $n=66, r=99(p<0: 001), y=0: 72 x+0.34$. 

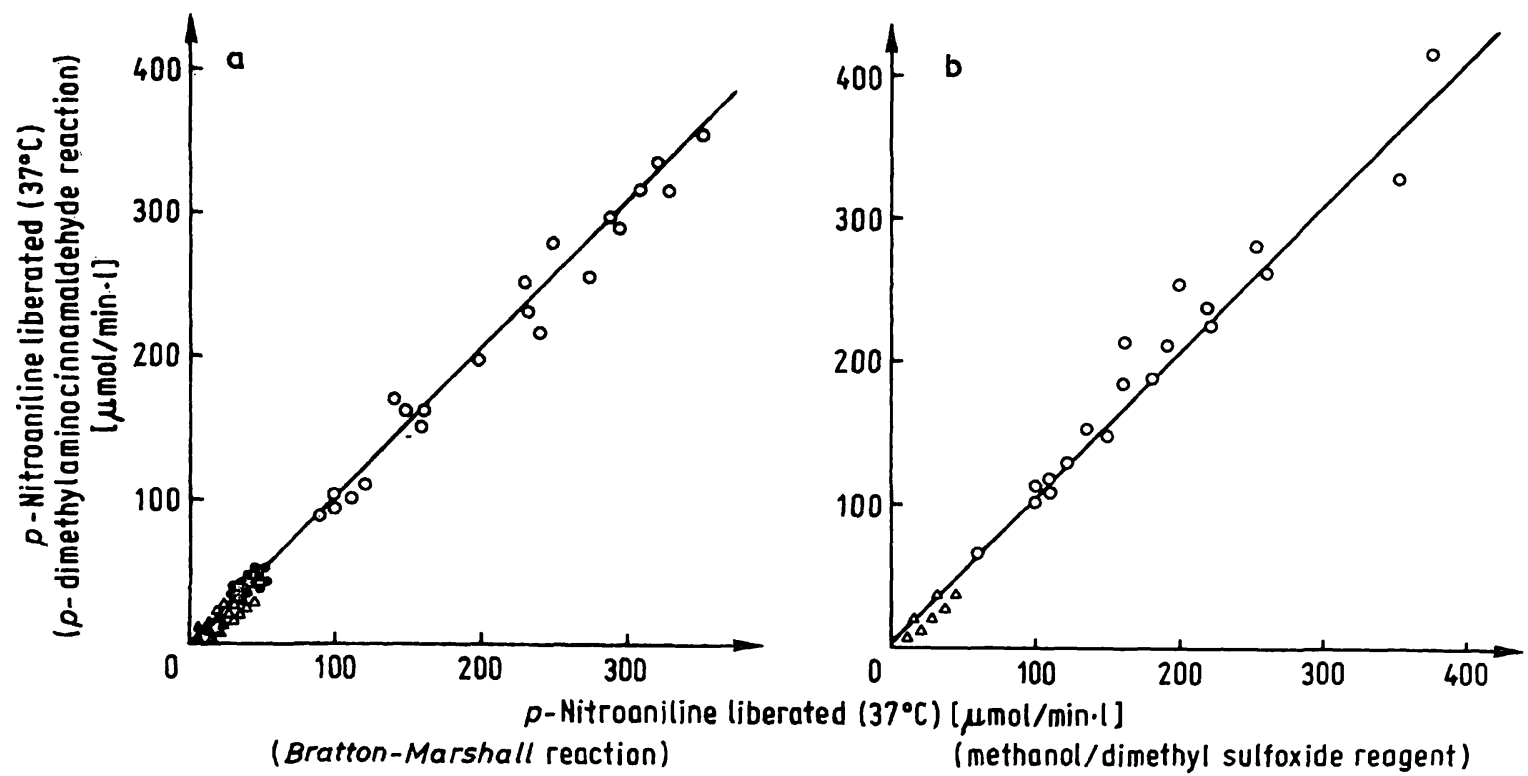

Fig. 3. Correlation between results of hydrolysis of nitroanilides obtained by the present method and the method with the BrattonMarshall reaction.

Normal serum with $\Delta$ cystineamide and $\Delta$ cysteineamide.

Pregnant serum with $\bullet$ cystineamide and 0 cysteineamide.

a) $n=74, x=0.99(p<0.001), y=0.99 x+0.73$.

b) $n=26, r=0.99(p<0.001), y=1.04 x+5.45$.

\section{Results}

\section{Cystyl-amino peptidase activity with various substrates in pregnant serum}

The enzyme activity with $L$-cystine-di- $\beta$-naphthylamide or $L$-cysteine- $\beta$-naphthylamide with advancing gestation, the highest levels were observed at term, being about three times the nonpregnant values, respectively. When $L$ cysteine- $\beta$-naphthylamide was used, greater sensitivity was observed, but the increasing rate was similar to that with $L$-cystine-di- $\beta$-naphthylamide (tab. 4 ). With $L$ cystine-bis- $p$-nitroanilide or S-benzyl- $L$-cysteine- $p$ nitroanilide, the enzyme activity was also significantly increased with advancing gestation, and at term the average values were about 8.5 and 34 times that of nonpregnant controls, respectively.

The enzyme activity with S-benzyl- $L$-cysteine-p-nitroanilide started to increase at about 16 weeks of pregnancy. However, the enzyme activity with the other three

Tab. 4. Cystyl-amino peptidase activity $\left(37^{\circ} \mathrm{C}\right)$ and oestriol level in serum of pregnant women and patients with hepatic disease

\begin{tabular}{|c|c|c|c|c|c|c|}
\hline \multirow[b]{3}{*}{$\begin{array}{l}\text { Non- } \\
\text { pregnant } \\
\text { women }\end{array}$} & \multirow{3}{*}{$\begin{array}{l}\text { No. of } \\
\text { cases } \\
20\end{array}$} & \multicolumn{3}{|c|}{$\begin{array}{l}\text { Enzyme activity, } \beta \text {-naphthylamine or } p \text {-nitroaniline liberated } \\
{[\mu \mathrm{mol} / \mathrm{min} \cdot 1](\overline{\mathrm{x}} \pm \mathrm{SD})}\end{array}$} & \multirow[b]{2}{*}{$\begin{array}{l}\text { S-benzyl- } L \text {-cysteine- } \\
p \text {-nitroanilide }\end{array}$} & \multirow{3}{*}{$\begin{array}{l}\begin{array}{l}\text { Oestriol level } \\
{[\mu \mathrm{g} / 1](\mathrm{x} \pm \mathrm{SD})}\end{array} \\
\quad 9.12 \pm 10.19\end{array}$} \\
\hline & & $\begin{array}{l}L \text {-cystine-di- } \beta \text { - } \\
\text { naphthylamide }\end{array}$ & $\begin{array}{l}L \text {-cysteine- } \beta \text { - } \\
\text { naphthylamide }\end{array}$ & $\begin{array}{l}L \text {-cystine-bis- } \\
p \text {-nitroanilide }\end{array}$ & & \\
\hline & & $3.65 \pm 1.04$ & $15.45 \pm 3.07$ & $3.91 \pm 2.53$ & $6.95 \pm 2.53$ & \\
\hline $\begin{array}{l}\text { Pregnant } \\
\text { (weêks) }\end{array}$ & & & & & & \\
\hline $\begin{array}{l}8 \\
12 \\
16 \\
20 \\
24 \\
28 \\
32 \\
36 \\
40 \\
\text { Hepatitis } \\
\text { Hepatic } \\
\text { cirrhosis }\end{array}$ & $\begin{array}{l}15 \\
15 \\
15 \\
15 \\
15 \\
15 \\
15 \\
15 \\
15 \\
25 \\
12\end{array}$ & $\begin{array}{l}3.63 \pm 0.59 \\
4.41 \pm 0.69 \\
3.98 \pm 0.63 \\
4.62 \pm 0.84 \\
5.45 \pm 1.18 \\
6.08 \pm 0.7 .6 \\
7.13 \pm 1.18 \\
9.65 \pm 1.88 \\
9.93 \pm 1.26 \\
5.03 \pm 1.39 \\
5.87 \pm 2.37\end{array}$ & $\begin{array}{ll}15.87 \pm 1.04 \\
16.57 \pm 1.58 \\
15.45 \pm 2.79 \\
17.41 \pm 4.47 \\
18.74 \pm 2.58 \\
19.23 \pm 2.51 \\
23.49 \pm 3.56 \\
39.16 \pm 5.59 \\
39.16 \pm 5.59 \\
31.74 \pm 7.48 \\
37.06 \pm 18.18\end{array}$ & $\begin{array}{r}3.12 \pm 1.61 \\
3.84 \pm 0.73 \\
4.27 \pm 1.66 \\
6.37 \pm 2.03 \\
10.79 \pm 5.29 \\
15.94 \pm 5.43 \\
16.37 \pm 6.88 \\
34.13 \pm 17.61 \\
34.35 \pm 13.84 \\
6.30 \pm 3.18 \\
7.10 \pm 2.10\end{array}$ & $\begin{aligned} 8.62 & \pm 3.48 \\
10.36 & \pm 1.95 \\
12.68 & \pm 3.40 \\
25.74 & \pm 14.05 \\
50.14 & \pm 25.10 \\
92.80 & \pm 16.95 \\
135.87 & \pm 41.04 \\
217.75 & \pm 48.40 \\
239.42 & \pm 40.50 \\
9.78 & \pm 3.26 \\
13.18 & \pm 7.82\end{aligned}$ & $\begin{array}{r}9.70 \pm 6.70 \\
9.02 \pm 5.00 \\
9.66 \pm 6.78 \\
22.20 \pm 19.77 \\
48.50 \pm 29.46 \\
91.28 \pm 49.97 \\
99.20 \pm 11.90 \\
232.33 \pm 72.76 \\
344.90 \pm 72.10 \\
-\end{array}$ \\
\hline
\end{tabular}


substrates started to increase at around 22 to 24 weeks of pregnancy (tab. 4). At term, the highest enzyme activity was obtained with S-benzyl- $L$-cysteine- $p$-nitroanilide, followed with $L$-cysteine- $\beta$-naph thylamide, $L$-cystinebis-p-nitroanilide, and $L$-cystine-di- $\beta$-naphthylamide.

Although the enzyme activities with these substrates were different, these values were well correlated with each other in pregnant serum (tab. 4).

\section{Cystyl-amino peptidase activity in normal subjects and} subjects with hepatic disease

With $L$-cysteine- $\beta$-naphthylamide the enzyme activity was greatly increased in acute or chronic hepatitis and hepatic cirrhosis as compared with the levels observed in normal subjects (tab. 4). The enzyme level in hepatic cirrhosis was as high as that at term of pregnancy. However, with $L$-cystine-di- $\beta$-naph thylamide, $L$-cystine-bis$p$-nitroanilide and S-benzyl- $L$-cysteine- $p$-nitroanilide the enzyme activity in the serum of patients with these diseases was only slightly increased, and the average levels of these substrates were significantly lower than that in pregnant serum (tab. 4). In contrast to pregnant serum, the highest enzyme levels in the serum of normal subjects and those with hepatic disease were observed with $L$-cysteine- $\beta$-naphthylamide, followed with S-benzyl$L$-cysteine- $p$-nitroanilide, $L$-cystine-bis- $p$-nitroanilide and $L$-cystine-di- $\beta$-naphthylamide.

\section{Oestriol level in pregnant serum}

The total oestriol level in serum started to increase at 20 to 24 weeks of gestation and the highest level was observed at term, being about 39 times greater than the value of nonpregnant serum (tab. 4).

\section{Correlation between cystyl-amino peptidase activity and oestriol level in pregnant serum}

A good correlation was observed between the oestriol level and the cystyl-amino peptidase activities, using $L$ cystine-di- $\beta$-naphthylamide, $L$-cysteine- $\beta$-naph thylamide, $L$-cystine-bis- $p$-nitroanilide or S-benzyl- $L$ cysteine-p-nitroanilide (fig. 4 and 5). The best correlation was observed between the oestriol level and the enzyme activity with S-benzyl- $L$-cysteine- $p$-nitroanilide.

\section{Cystyl-amino peptidase activity in human placenta and various rat tissues}

In the placenta, the enzyme activity with S'benzyl- $L$ cysteine-p-nitroanilide was the highest, followed by $L$-cysteine- $\beta$-naph thylamide, $L$-cystine-bis- $p$-nitroanilide and $L$-cystine-di- $\beta$-naphthylamide (tab. 5). A similar pattern of enzyme activity was observed in various rat tissues such as liver, brain, heart etc., but in the kidney and small intestine the greatest enzyme activity was obtained with $L$-cysteine- $\beta$-naphthylamide, followed
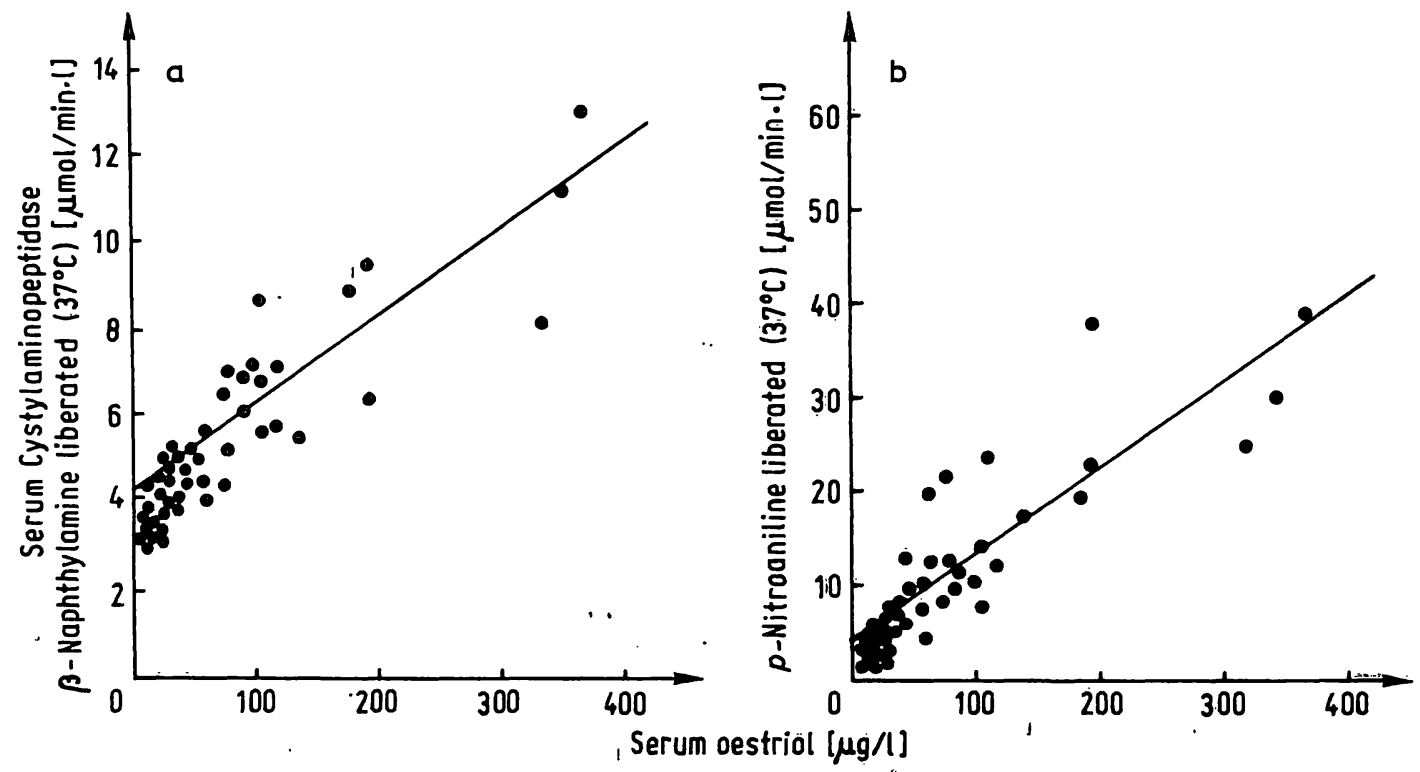

Fig. 4. Correlation between cystyl-amino peptidase activity with cystineamides and oestriol levels in pregnant serum.

a) Substrate: $L$-cystine-di- $\beta$-naphthylamide $\mathrm{n}=61, \mathrm{r}=0.81(\mathrm{p}<0.001), \mathrm{y}=0.020 \mathrm{x}+4.13$.

b) Substrate: $L$-cystine-bis-p-nitroanilide $\mathrm{n}=61, \mathrm{r}=0.81 .(\mathrm{p}<0.001), \mathrm{y}=0.087 \mathrm{x}+4.84$. 


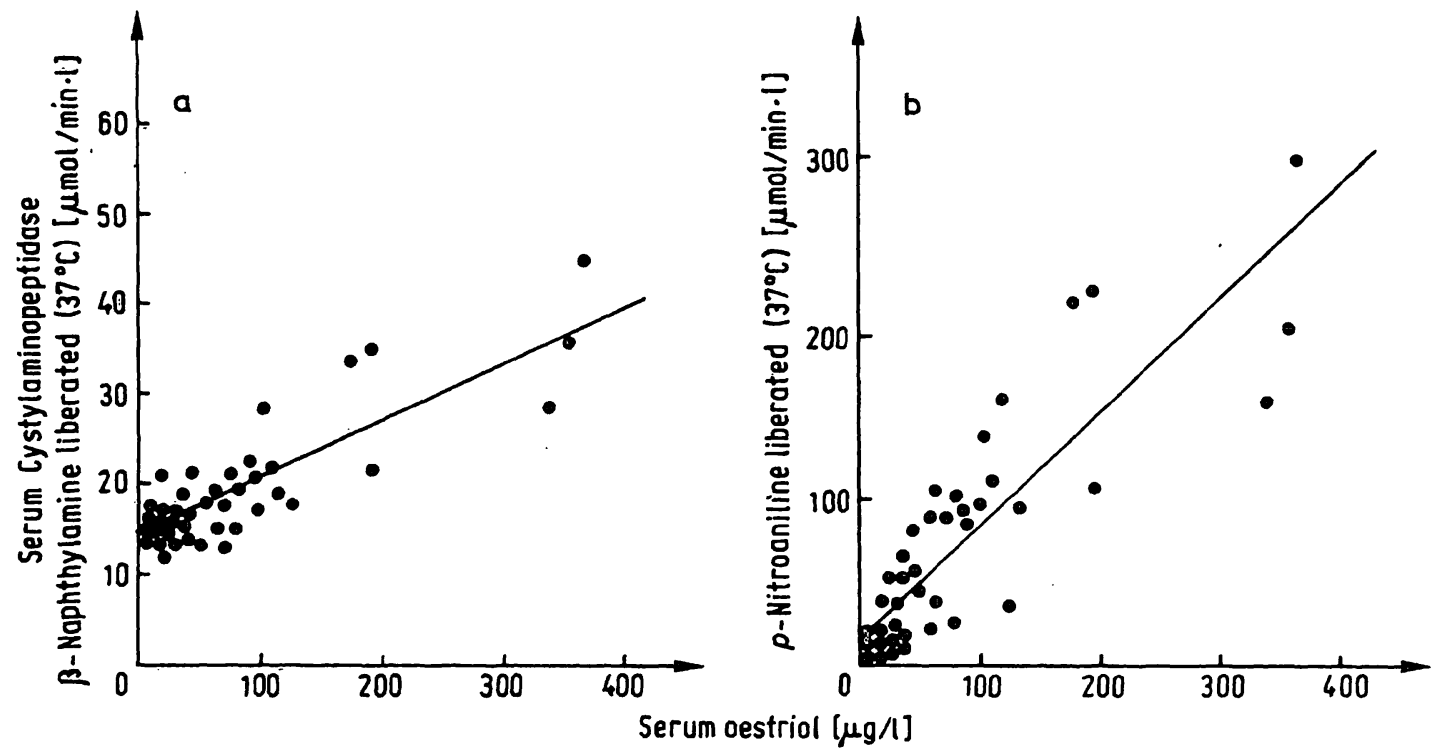

Fig. 5. Correlation between cystyl-amino peptidase activity with cysteineamides and oestriol levels in pregnant serum.

a) Substrate: $L$-cysteine- $\beta$-naphthylamide $n=61, r=0.82(p<0.001), y=0.06 x+15.29$.

b) Substrate: S-benzyl- $L$-cysteine-p-nitroanilide $\mathrm{n}=61, \mathrm{r}=0.87(\mathrm{p}<0.001), \mathrm{y}=0.72 \mathrm{x}+16.03$.

Tab. 5. Cystyl-amino peptidase activity $\left(37^{\circ} \mathrm{C}\right)$ in human placenta and various rat tissues.

\begin{tabular}{|c|c|c|c|c|c|}
\hline & \multirow[b]{2}{*}{$\begin{array}{l}\text { No. of } \\
\text { cases }\end{array}$} & \multicolumn{3}{|c|}{$\begin{array}{l}\text { Enzyme activity, } \beta \text {-naphthylamine or } p \text {-nitroaniline liberated } \\
\text { [nmol/min } \cdot \mathrm{mg} \text { protein] }(\overline{\mathrm{x}} \pm \mathrm{SD})\end{array}$} & \multirow[b]{2}{*}{$\begin{array}{l}\text { S-benzyl- } L \text {-cysteine- } \\
p \text {-nitroanilide }\end{array}$} \\
\hline & & $\begin{array}{l}L \text {-cystine-di- } \beta \text { - } \\
\text { naphthylamide }\end{array}$ & $\begin{array}{l}L \text {-cysteine- } \beta \text { - } \\
\text { naphthylamide }\end{array}$ & $\begin{array}{l}L \text {-cystine-bis- } \\
p \text {-nitroanilide }\end{array}$ & \\
\hline \multicolumn{6}{|l|}{ Human } \\
\hline Placenta & 6 & $0.85 \pm 0.23$ & $5.75 \pm 1.65$ & $1.29 \pm 0.53$ & $10.81 \pm 4.10$ \\
\hline \multicolumn{6}{|l|}{ Rat } \\
\hline $\begin{array}{l}\text { Brain } \\
\text { Heart } \\
\text { Liver } \\
\text { Kidney } \\
\text { Small intestine }\end{array}$ & $\begin{array}{l}6 \\
6 \\
6 \\
6 \\
6\end{array}$ & $\begin{array}{l}0.84 \pm 0.26 \\
0.42 \pm 0.12 \\
1.44 \pm 0.41 \\
1.03 \pm 0.26 \\
0.80 \pm 0.17\end{array}$ & $\begin{array}{r}5.80 \pm 1.21 \\
3.28 \pm 1.10 \\
6.19 \pm 1.78 \\
39.99 \pm 13.53 \\
15.20 \pm 5.19\end{array}$ & $\begin{array}{l}1.16 \pm 0.53 \\
0.92 \pm 0.26 \\
1.21 \pm 0.35 \\
6.98 \pm 1.78 \\
3.01 \pm 1.02\end{array}$ & $\begin{array}{r}11.54 \pm 2.69 \\
6.22 \pm 1.97 \\
8.77 \pm 2.17 \\
34.95 \pm 8.64 \\
14.07 \pm 3.58\end{array}$ \\
\hline
\end{tabular}

with $S=b e n z y l-L$-cysteine-p-nitroanilide and cystineamides.

\section{Effect of heating, methionine, and $\mathrm{Co}^{2+}$ on enzyme activity}

The effect of heat, methionine, and $\mathrm{Co}^{2+}$ on the enzyme activity was studied as described by previous workers (66). The activity of cystyl-amino peptidase in various sera with various substrates studied was inhibited by heat and by methionine (tab. 6). The enzyme activity with S-benzyl-L-cysteine-p-nitroanilide was inhibited by $\mathrm{Co}^{2+}$, while the enzyme activity with $L$-cysteine$\beta$-naphthylamide was stimulated by this ion (tab. 6). With $L$-cystine-bis- $p$-nitroanilide, the enzyme activity in sera of nonpregnant women and patients with hepatic cirrhosis was inhibited by $\mathrm{Co}^{2+}$, but that in pregnant sera was stimulated. With $L$-cystine-di- $\beta$-naphthylamide, the enzyme activity in these sera was not influenced by $\mathrm{Co}^{2+}$.

\section{Discussion}

The cystyl-amino peptidase in the serum of pregnant women was studied with $L$-cystine-di- $\beta$-naphthylamide, $L$-cystine-bis- $p$-nitroanilide, $L$-cysteine- $\beta$-naphthylamide and S-benzyl- $L$-cysteine- $p$-nitroanilide. The cystyl-amino peptidase activities measured with theșe substrates were increased with advancing gestation, the highest levels being obtained at term. The activity 
Tab. 6. Effect of heating, methionine and $\mathrm{Co}^{2+}$ on cystyl-amino peptidase activity $\left(37^{\circ} \mathrm{C}\right)$ in serum. $L$-Methionine and $\mathrm{CoCl}_{2}$ were used at a concentration of 20 and $0.5 \mathrm{mmol} / 1$ of the reaction mixture, respectively. Serum was heated at $60^{\circ} \mathrm{C}$ for $30 \mathrm{~min}$ just prior to the assay of enzyme activity. Figures in parentheses are remaining activity fractions referred to the control values.

\begin{tabular}{|c|c|c|c|c|c|}
\hline & \multicolumn{4}{|c|}{$\beta$-Naphthylamine or $p$-nitroaniline liberated $[\mu \mathrm{mol} / \mathrm{min} \cdot 1]$} & \multirow[b]{2}{*}{$\mathrm{Co}^{2+}$} \\
\hline & Case No. & None & $L$-Methionine & Heating & \\
\hline \multicolumn{6}{|c|}{$L$-Cystine-di- $\beta$-naphthylamide } \\
\hline Normal & $\begin{array}{l}1 . \\
2 . \\
3 .\end{array}$ & $\begin{array}{l}1.79 \\
2.18 \\
1.78\end{array}$ & $\begin{array}{l}1.89(0.50) \\
0.46(0.21) \\
0.36(0.20)\end{array}$ & $\begin{array}{l}0.45(0.25) \\
0.69(0.32) \\
0 \quad(0)\end{array}$ & $\begin{array}{l}1.70(0.95) \\
2.29(1.05) \\
1.85(1.02)\end{array}$ \\
\hline Pregnant & $\begin{array}{l}1 . \\
2 . \\
3 .\end{array}$ & $\begin{array}{l}7.57 \\
4.66 \\
3.39\end{array}$ & $\begin{array}{l}5.73(0.75) \\
3.02(0.65) \\
1.59(0.47)\end{array}$ & $\begin{array}{l}0.46(0.61) \\
0 \quad(0) \\
0.53(0.16)\end{array}$ & $\begin{array}{l}7.57(1.00) \\
3.72(0.80) \\
3.39(1.00)\end{array}$ \\
\hline $\begin{array}{l}\text { Hepatic } \\
\text { cirrhosis }\end{array}$ & $\begin{array}{l}1 . \\
2 . \\
3 .\end{array}$ & $\begin{array}{l}4.66 \\
2.64 \\
2.86\end{array}$ & $\begin{array}{l}1.17(0.25) \\
0.85(0.32) \\
0.89(0.31)\end{array}$ & $\begin{array}{l}2.33(0.50) \\
1.27(0.48) \\
1.61(0.56)\end{array}$ & $\begin{array}{l}4.42(0.95) \\
2.65(1.00) \\
2.95(1.03)\end{array}$ \\
\hline \multicolumn{6}{|c|}{$L$-Cystine-bis- $p$-nitroanilide } \\
\hline Normal & $\begin{array}{l}1 . \\
2 . \\
3 .\end{array}$ & $\begin{array}{l}3.43 \\
2.84 \\
1.98\end{array}$ & $\begin{array}{ll}0 & (0) \\
0 & (0) \\
0 & (0)\end{array}$ & $\begin{array}{l}2.07(0.60) \\
1.95(0.69) \\
1.27(0.64)\end{array}$ & $\begin{array}{l}2.14(0.62) \\
1.89(0.67) \\
1.38(0.67)\end{array}$ \\
\hline Pregnant & $\begin{array}{l}1 . \\
2 . \\
3 .\end{array}$ & $\begin{array}{l}20.28 \\
17.78 \\
18.58\end{array}$ & $\begin{array}{l}15.61(0.77) \\
12.58(0.71) \\
14.18(0.75)\end{array}$ & $\begin{array}{l}0.66(0.03) \\
1.66(0.09) \\
1.46(0.08)\end{array}$ & $\begin{array}{l}29.89(1.47) \\
23.68(1.33) \\
24.51(1.30)\end{array}$ \\
\hline $\begin{array}{l}\text { Hepatic } \\
\text { cirrhosis }\end{array}$ & $\begin{array}{l}1 . \\
2 . \\
3 .\end{array}$ & $\begin{array}{l}10.95 \\
11.14 \\
10.10\end{array}$ & $\begin{array}{l}0.56(0.05) \\
0.59(0.05) \\
1.22(0.12)\end{array}$ & $\begin{array}{l}7.24(0.66) \\
8.21(0.74) \\
5.84(0.58)\end{array}$ & $\begin{array}{l}4.39(0.45) \\
5.39(0.48) \\
5.19(0.51)\end{array}$ \\
\hline \multicolumn{6}{|c|}{$L$-cysteine- $\beta$-naphthylamide } \\
\hline Normal & $\begin{array}{l}1 . \\
2 . \\
3 .\end{array}$ & $\begin{array}{l}23.55 \\
20.80 \\
21.18\end{array}$ & $\begin{array}{l}4.35(0.19) \\
3.68(0.18) \\
4.20(0.20)\end{array}$ & $\begin{array}{l}17.57(0.74) \\
13.25(0.64) \\
19.32(0.92)\end{array}$ & $\begin{array}{l}30.80(1.31) \\
26.32(1.27) \\
27.78(1.31)\end{array}$ \\
\hline Pregnant & $\begin{array}{l}1 . \\
2 . \\
3 .\end{array}$ & $\begin{array}{l}33.88 \\
46.39 \\
38.98\end{array}$ & $\begin{array}{l}19.68(0.58) \\
20.09(0.43) \\
11.85(0.30)\end{array}$ & $\begin{array}{r}6.12(0.18) \\
10.65(0.23) \\
20.20(0.52)\end{array}$ & $\begin{array}{l}49.18(1.45) \\
58.20(1.25) \\
45.70(1.17)\end{array}$ \\
\hline $\begin{array}{l}\text { Hepatic } \\
\text { cirrhosis }\end{array}$ & $\begin{array}{l}1 . \\
2 . \\
3 .\end{array}$ & $\begin{array}{l}38.53 \\
47.29 \\
30.54\end{array}$ & $\begin{array}{l}4.71(0.12) \\
7.36(0.16) \\
5.15(0.17)\end{array}$ & $\begin{array}{l}23.54(0.16) \\
22.64(0.48) \\
15.09(0.49)\end{array}$ & $\begin{array}{l}43.60(1.13) \\
55.21(1.17) \\
38.09(1.24)\end{array}$ \\
\hline \multicolumn{6}{|c|}{$\begin{array}{l}\text { S-Benzyl- } L \text {-cysteine- } p \text { - } \\
\text { nitroanilide }\end{array}$} \\
\hline Normal & $\begin{array}{l}1 . \\
2 . \\
3 .\end{array}$ & $\begin{array}{l}6.73 \\
5.49 \\
6.95\end{array}$ & $\begin{array}{l}0.77(0.12) \\
0.82(0.15) \\
0.90(0.13)\end{array}$ & $\begin{array}{l}3.28(0.49) \\
2.10(0.38) \\
2.98(0.43)\end{array}$ & $\begin{array}{l}6.08(0.90) \\
4.44(0.81) \\
5.90(0.85)\end{array}$ \\
\hline Pregnant & $\begin{array}{l}1 . \\
2 . \\
3 .\end{array}$ & $\begin{array}{l}348.08 \\
253.11 \\
240.50\end{array}$ & $\begin{array}{r}113.55(0.33) \\
81.52(0.32) \\
76.95(0.32)\end{array}$ & $\begin{array}{l}8.36(0.02) \\
0.88(0.00) \\
3.60(0.02)\end{array}$ & $\begin{array}{l}197.10(0.57) \\
148.04(0.59) \\
139.49(0.58)\end{array}$ \\
\hline $\begin{array}{l}\text { Hepatic } \\
\text { cirrhosis }\end{array}$ & $\begin{array}{l}1 . \\
2 . \\
3 .\end{array}$ & $\begin{array}{l}16.26 \\
17.07 \\
13.20 \\
\end{array}$ & $\begin{array}{l}1.15(0.07) \\
1.06(0.06) \\
0.85(0.07)\end{array}$ & $\begin{array}{r}8.65(0.53) \\
10.59(0.62) \\
\overline{7} .26(0.55) \\
\end{array}$ & $\begin{array}{l}13.84(0.85) \\
15.31(0.89) \\
11.35(0.86) \\
\end{array}$ \\
\hline
\end{tabular}

with cysteineamides was greater than that with the corresponding cystineamides. The increase in the enzyme activity in normal pregnancy, using any of the above substrates, followed the S-shaped curve, which previous workers have described $(14,24)$. The increasing rate and the range of the enzyme activities were different for each substrate used. This difference is very important in the clinical assessment of placental function. The enzyme activity with S-benzyl- $L$-cysteine- $p$-nitroanilide started to increase at about 16 weeks of gestation, while the enzyme activity with the other three substrates started to increase at about 22 to 24 weeks. The rate of increase of enzyme activity with S-benzyl- $L$ cysteine- $p$-nitroanilide was far greater than with other substrates with advancing gestation. At term, the highest enzyme activity was obtained with S-benzyl$L$-cysteine- $p$-nitroanilide, followed by $L$-cysteine- $\beta$ naphthylamide and cystineamides. However, the enzyme levels with these substrates correlated well, thus confirming the previous studies $(47,49,55)$. In contrast, in sera of healthy nonpregnant females and males, the enzyme activity was the highest with $L$ cysteine- $\beta$-naphthylamide, followed by S-benzyl$L$-cysteine- $p$-nitroanilide and cystineamides.

The urinary excretion pattern of oestriol is useful for evaluating normal and abnormal pregnancy (67, 68 ); although the precise meaning and usefulness of 
oestriol measurement during pregnancy remain controversial. Clinically, a decline in oestriol excretion may indicate a failing feto-placental unit, whereas a normal value generally indicates fetal well being. Similarly, the plasma oestriol concentration provides a ready indication of the functional status of the feto-placental units in the absence of renal failure $(59,60)$. It has suggested that plasma oestriol values would be more useful for determining feto-placental viability than the corresponding urinary measurement (69-71). Although previous studies have shown correlation between the urinary oestrogen levels and the serum cystyl-amino peptidase activity $(21,22,28,29,72-74)$, it is not well understood with respect to the relationship between the serum cystyl-amino peptidase activity and the plasma oestriol level. In this study, therefore, the plasma oestriol level and the cystyl-amino peptidase activity with various substrates were studied simultaneously in pregnancy. Serum oestriol in pregnancy gradually increased with advancing gestation, which correlated with increased cystyl-amino peptidase activity. It was very markedly increased at the third trimester. All cystyl-amino peptidase activities measured with four substrates correlated well with the plasma oestriol levels, but the best correlation was observed between the oestriol level and the cystyl-amino peptidase activity with S-benzyl- $L$-cysteine- $p$-nitroanilide.

In the serim of hepatic disease such as hepatitis and hepatic cirrhosis, the cystyl-amino peptidase activity is reported to be increased (66). In this study the cystylamino peptidase activity in the serum of hepatic disease was increased with all four substrates. The enzyme activity with $L$-cysteine- $\beta$-naphthylamide was greatly increased, but that with S-benzyl- $L$-cysteine-p-nitroanilide and cystineamides was not so markedly increased. Since the enzyme activity in the liver was the highest with S-benzyl- $L$-cysteine-p-nitroanilide, followed by $L$-cysteine- $\beta$-naphthylamide, then cystineamides, the present serum enzyme pattern of hepatic disease suggests that in hepatic disease the enzyme hydrolyzing $L$ cysteine- $\beta$-naphthylamide was more permeable to the hepatic cell membrane than the enzyme hydrolyzing $S$-benzyl- $L$-cysteine- $p$-nitroanilide. Likewise, in serum of nonpregnant healthy individuals, the highest serum enzyme value was obtained with $L$-cysteine- $\beta$-naphthylamide.

In contrast, in pregnant serum cystyl-amino peptidase activity with S-benzyl- $L$-cysteine- $p$-nitroanilide was far greater than that with $L$-cysteine- $\beta$-naph thylamide. The enzyme activity pattern of pregnant serum with these different substrates was quite similar to that in the placental tissue, in which the highest value was obtained with S-benzyl- $L$-cysteine-p-nitroanilide. This supports the view that the cystyl-amino peptidase activity in pregnant serum probably originates from the placenta, as previously suggested $(5,75,76)$.
A question arises with respect to the mechanism of hydrolysis of these substrates by serum and various tissue homogenates. Under the conditions of this study, in various sera and tissue homogenates the maximal activity of enzyme hydrolyzing S-benzyl- $L$-cysteine- $p$ nitroanilide was observed at about $\mathrm{pH} 7.0$ and that of enzyme hydrolyzing $L$-cysteine- $\beta$-naph thylamide was at about $\mathrm{pH} 6$ in cacodylate, tris-maleate or citrate-phosphate buffer. The enzyme activity with S-benzyl- $L$ cysteine-p-nitroanilide in various sera was inhibited by $\mathrm{Co}^{2+}$, but that with $L$-cysteine- $\beta$-naphthylamide was stimulated by this ion. With $L$-cystine-bis- $p$-nitroanilide the enzyme activity in serum of nonpregnant women and patients with hepatic cirrhosis was inhibited by $\mathrm{Co}^{2+}$, but that in pregnant serum was enhanced by this ion. With $L$-cystine-di- $\beta$-naphthylamide, the enzyme activity of various sera was not influenced by $\mathrm{Co}^{2+}$. Tiderström \& Heinegard (66) have showed the inhibiting effect of $\mathrm{Co}^{2+}$ on the enzyme activity with S-benzyl- $L$ cysteine- $p$-nitroanilide. Furthermore, they demonstrated that the enzyme activity with $L$-cystine-bis- $p$ nitroanilide in serum of nonpregnant women and patients with hepatic disease was inhibited by this ion, whereas that in pregnant serum was stimulated. The present study confirmed this finding. These results together indicate some difference in the mechanism of the hydrolysis of these substrates by serum, suggesting that the cystyl-amino peptidase activity determined with synthetic substrates not only measures oxytocinase, but is also influenced by some other amino peptidase of uncertain origin. The purified oxytocinase activity was reported to be inhibited by $\mathrm{Co}^{2+}$ by Tuppy \& Wintersberger (77). Since in this study the enzyme activity with S-benzyl- $L$-cysteine$p$-nitroanilide in various sera was uniformly inhibited by $\mathrm{Co}^{2+}$, S-benzyl- $L$-cysteine- $p$-nitroanilide may be a more reliable substrate for measuring oxytocinase in serum or tissues.

Because of the presence of various proteases or amidases in serum, the absence of specificity of substrate is important. Although absolute substrate differentiation for measuring cystyl-amino peptidase activity in serum cannot be expected (78), evidence assembled in this study suggests high efficacy of S-benzyl- $L$-cysteine$p$-nitroanilide for measuring serum cystyl-amino peptidase for the assessment of placental function. However, further study is necessary, since a very few clinical studies are available at present with respect to the serum enzyme activity with this substrate.

The proposed method in this study is sensitive and simpler than the previous colorimetric and spectrophotometric methods. The present method does not employ centrifugation and uses a single color reagent. In addition, this method has the advantage that it can be performed without using a reaction rate analyzer or other sophisticated equipment. 


\section{References}

1. Rimbach, E. (1974), Methods of Enzymatic Analysis (Bergmeyer, H. U. ed.), Verlage Chemie-Academic Press, p. 56-62.

2. Fekete, K. (1930), Endokrinologie 7, 364-369.

3. Werle, E. \& Effkemann, G. (1941), Arch. Gynäkol 171, 286-290.

4. Werle, E., Hewelke, A. \& Buthman, K. (1941), Biochem. Z. 309, 270-282.

5. Page, E. W. (1946), Am. J. Obst. Gynecol. 52, 1014-1022.

6. Semm, K. (1955), Klin. Wochenschr. 33, 817-818.

7. Müller-Hartburg, W., Nesvalba, H. \& Tuppy, A. (1959), Arch. Gynäkol. 191, 442-456.

8. Riad, A. M. (1962), J. Obst. Gynecol. Br. Comm. 64, 409-416.

9. Bernhard, J. \& Semm, K. (1964), Zbl. Gynäkol. 86, 1691 $-1693$.

10. Melander, S. E. J. (1965), Acta Endocrinol. 48, Suppl 96, 9-94.

11. Ryden, G. (1966), Acta Obst. Gynecol Scand. 45, Suppl. 3, 5-105.

12. Klimek, R. \& Bieniasz, A. (1969), Am. J. Obst. Gynecol. 104, 959-963.

13. Poch, G., Martinez, A. L., Holzer, E. \& Hohlweg, N. (1970), Arch. Gynäkol 208, 416-429.

14. Chapman, L., Burrows-Peakin, R., Jowett, T. P., Rege, V. P. \& Silk, E. (1973), Clin. Chim. Acta 47, 89-92.

15. Carter, E. R., Goodman, L. V., De Hean, R. M. \& Sobota, J. T. (1974), Am. J. Obst. Gynecol. 77, 76-81.

16. Roth, H., Nagel, R. \& Stark, K.-H. (1976), Zbl. Gynäkol. 98, 73-79.

17. Babuna, C. \& Yenen, E. (1966), Am. J. Obst. Gynecol. 94, 868-875.

18. Babuna, C. \& Yenen, E. (1966), Am. J. Obst. Gynecol. 95, 925-934.

19. Josephides, E. C. H. \& Turkington, V. E. (1969), J. Obst. Gynecol. Br. Comm. 74, 258-261.

20. Hensleigh, P. A. \& Krantz, K. E. (1970), Am. J. Obst. Gynecol. $107,1233-1240$.

21. Hurry, D. J., Tovey, J. E., Robinson, D. A., Beynon, C. L. \& Cooper, K. (1972), Br. J. Obst. Gynecol. 79, 788-793.

22. Petrucco, O. M., Cellar, K. \& Fishtall, A. (1973), J. Obst. Gynecol. Br. Comm. 80, 499-507.

23. Pathak, C., Himaya, A. \& Mosher, R. (1974), Am. J. Obst. Gynecol. 120, 32-39.

24. Chapman, L., Burrows-Peskin, R., Rege, V. P. \& Silk, E. (1975), Br. J. Obst. Gynecol. 82, 278-284.

25. Chapman, L., Burrows-Peakin, R., Rege, V. P. \& Silk, E. (1976), Br. J. Obst. Gynecol. 83, 238-240.

26. Spellacy, W. H., Usategui-Gomez, N. \& Fernandez-de Castro, A. (1977), Am. J. Obst. Gynecol. 127, 10-16.

27. Durham, B. H. \& Rewell, R. E. (1979), J. Clin. Pathol. 32, 318-320.

28. Watson, D., Siddiqui, A., Stafford, J. E. H., Giffard, S. \& Hewitt, V. (1973), J. Clin. Pathol. 26, 294-300.

29. Curzen, P. \& Varma, P. (1973), Am. J. Obst. Gynecol. $115,929-932$.

30. Rangarajan, N. S. \& La Croix, G. E. (1973), Int. J. Obst. Gynecol. 11, 85-89.

31. Bigges, J. S. G. (1975), Obst. Gynecol. 45, 227-233.

32. Hensleigh, P. A., Cheatum, S. G. \& Spellacy, W. N. (1977), Am. J. Obst. Gynecol. 129, 675-678.

33. Tuppy, H. \& Nesvadba, H. (1957), Monatsh. Chem. 88, 977-988.

34. Wada, H. (1966), J. Jap. Obst. Gynecol. Soc. 18, 1077-1082.

35. Skramosky, V., Vacerek, B., Bendova, M. \& Tranka, V. (1971), Clin. Chim. Acta 32, 140-141.

36. Chapman, L., Silk, E., Skupny, A. \& Tooth, E. A. (1971), J. Obst. Gynecol. Br. Comm. 78, 435-443.

37. Kleiner, H. \& Brouet-Yager, M. (1973), Clin. Chim. Acta 48, 299-309.

38. Brandle, E., Semm, K. \& Krieger, W. (1975), Arch. Gynäkol. 219, 466-469.

39. Tuppy, H., Wiesbauern, U. \& Wintersberger, E. (1962), Hoppe Seyler's Z. Physiol. Chem. 329, 278-288.

40. Tovey, J. E. (1969), Clin. Biochem. 2, 289-310.
41. Small, C. W. \& Watkins, W. B. (1971), Enzymologia 41, 121-128.

42. Oudheusden, A. P. M., van (1971), Clin. Chim. Acta 32, 140-141.

43. Peeters, J. A. B. M. (1972), Clin. Chem. 18, 563-564.

44. Watkins, W. B. \& Small, C. W. (1972), Biochem. Med. 6, 82-89.

45. Usạtegui-Gomez, M., Tarbutton, P. \& Yeager, F. (1973), Clin. Chim. Acta 47, 409-415.

46. Bull, T., van \& Oudheusden, A. P. M., van (1974), Clin. Chim. Acta 54, 263-268.

47. Cristensen, A. \& Hagelid, P. E. (1975), Acta Endocrinol. 78, 364-372.

48. Roth, H., Nagel, R. \& Stark, K.-H. (1976), Zbl. Gynäkol. 98, 73-79.

49. Holanska-Nalepa, I. (1977), Clin. Chim. Acta 75, 5-8.

50. Wintersberger, E., Müller-Hartburg, W. \& Tuppy, H. (1966), Clin. Chim. Acta 14, 786-792.

51. Uete, T., Morikawa, M., Shimizu, S., Shimano, N. \& Konishi, A. (1977), Clin. Biochem. 10, 193-196.

52. Oudheusden, A. P. M., vañ (1972), Z. Klin. Chem. Klin. Biochem. 10, 345-346.

53. Tovey, J. E., Dawson, P. J. G. \& Fellowes, K. P. (1973), Clin. Chem. 19, 756-761.

54. Small, C. W. \& Watkins, W. B. (1974), Biochem. Med. 9, 103-112.

55. Chapman, L., Burrẹws-Peakin, R., Rege, V. P. \& Silk, E. (1974), Clin. Chim Acta 51, 335-339.

56. Small, C. W. \& Watkins, W. B. (1975), Clin. Biochem. 8, 124-134.

57. Haya, P. R. van (1975), Clin. Chim. Acta 63, 193-196.

58. Durham, B. H. (1976), Clin. Chem. 22, 79-82.

59. Levitz, M. \& Young, B. K. (1977), Vitamine and Hormone 35, 109-147.

60. Unnerus, H. A. (1979), Acta Endocrinol. 91, Suppl. 226, 1-80.

61. Layne, E. (1957), Methods in Enzymology (Colowick, S. P. \& Kạplan, N. O., eds.) Acad. Press Inc, N.Y., Vol. III, 450-451.

62. Sạkai, S., Sụuki, K., Mori, H. \& Fujino, M. (1960), Japan Analyst 9, 862-864.

63. Matsutani, M., Takehisa, M., Fukunami, R., Shimasue, A. \& Kikukawa, N. (1967), Rinshokensa 11, 300-302.

64. Lehmann, P., Lill, H., Schaich, E. \& Grassl, M. (1978), Enzyme in Health and Disease (Goldberg, D. M. \& Wilkinson, J. H., eds.) S. Karger, Basel, p. 107-114.

65. Bratton, A. C. \& Marshall, E. K. Jr. (1939), J. Biol. Chem. $128,537-550$.

66. Tiderström, G. \& Heinegard, D. (1978), Clin. Chim. Acta 88, 293-304.

67. Ostergard, D. R. (1973), Obst. Gynecol. Surv. 28, 215-231.

68. Lundy, L. E., Wu, C. H. \& Lee, S. G. (1973), Clin. Obst. Gynecol. 16, 279-297.

69. Nachtigall, L., Bassett, M., Hogsander, U., Slagle, S. \& Levitz, M. (1966), J. Clin. Endocrinol. 26, 941-948.

70. Trolle, D., Bock, J. E. \& Gaede, P. (1976), Am. J. Obst. Gynecol. 126, 834-841.

71. Kirkish, L. S., Barcloy, M. L., Parra, J. B., Compton, A. A. \& McCann, D. S. (1978), Clin. Chem. 24, 1830-1832.

72. Biswas, S., Hindocha, P. \& Dewhurst, C. J. (1972), J. Endocrinol. 54, 251-261.

73. Fort, A. T., Ragland, J. B., Morgan, B. S., Koiken, L. Robert, S. (1973), Int. J. Gynecol. Obst. 11, 96-105.

74. Ward, H., Rochman, H., Vamavides, L. A. \& Whyley, G. A. (1973), Am. J. Obst. Gynecol. 116, 1105-1113.

75. Page, E. W., Titus, M. A., Mohun, G. \& Glendening, M. B. (1961), Am J. Obst. Gynecol. 82, 1090-1095.

76. Oya, M., Yoshino, S., Mizutani, S. \& Wakabayashi, T. (1974), Gynecol. Invest. 5, 276-283.

77. Tuppy, H. \& Wintersberger, E. (1960), Monatsh. Chem. 91, 1001-1010.

78. Rybak, M., Rybakiova, B. \& Petakova, M. (1978), Experientia 34, 28-29. 